\title{
Some preliminary botanical remarks about the frescoes of the Oratory of San Pellegrino at Bominaco (L'Aquila)
}

\begin{abstract}
Lucchese, F: Some preliminary botanical remarks about the frescoes of the Oratory of San Pellegrino at Bominaco (L'Aquila). — Bocc. 28: 417-424. 2019. — ISSN: 1120-4060 printed, 2280-3882 online.

Some frescoes of the small building of the Oratory of San Pellegrino (Bominaco - village of Caporciano, in the Navelli plain) are illustrated and commented for the first time from a botanical point of view. In addition to a general commentary of the works, a description is provided of the botanical details and the landscape view of the two cycles of Christ's Childhood and Passion. While the floral elements linked to the tradition are repeated, such as stylised lilies and acanthi, there are new floral motifs of some oval and heart-shaped plants that can perhaps be attributed to violets throughout their vegetative cycle until flowering and fructification. A comment is made about the trees portrayed with sinuous lines and thick crown from which the leaves emerge; finally, some forms similar to acanthi can be referred to plants of cabbage and cauliflower, which were grown in Benedictine monasteries.
\end{abstract}

Key words: Christ's passion, Byzantine art, Benedictine garden.

\section{Introduction}

The Oratory of San Pellegrino is located near Bominaco (village of Caporciano) on the orographic right of the Navelli plain, famous up to this very day for the cultivation of saffron, probably introduced there, according to tradition, by St. Bernardine of Siena (13801444). The building, rectangular in shape, is part of a wider complex belonging to the Benedictine Monastery; the monks also built here the Church of Santa Maria Assunta on a pre-existing building of the eight century devoted to a Syrian saint, St. Peregrine, who lived between the third and fifth centuries. The monastery experienced many difficulties because of the dispute of the monks with the dioceses of L'Aquila and Valva, whose ancient Lombard roots can be recognised; the complex was destroyed by Braccio da Montone (1368-1424) during the war between the Angevins and Aragonese, which was waged near L'Aquila, where the commander died; surely for the respect of this sacred place, the church and the oratory were spared. For this reason, the building has reached our times almost undamaged, except for a probable eighteenth-century addition of a portico 
opposite one of the entrances. The frescos and perhaps the entire building date back to 1263 as reported in an inscription on the inside, referring to Abbot Teodino's will; another inscription bearing Charles' name may refer to Charlemagne or Charles of Anjou.

The architectural complex and the description of the frescoes were investigated for their importance in several studies, among which we had the opportunity of consulting in an original way that by Maria Della Valle (2006) in which other authors are mentioned, including Baschet (1991) for the frescoes and De Dominicis (1970) for the restoration works. Other monographs are of a popular nature (Dander 1979; Lo Iacono 1993 \& 1995). More recent is the work by Arbace (2012) together with other authors.

This work, of a preliminary nature, takes into consideration only some figures of the two cycles (Christ's Childhood and Passion) waiting to have more details and documents on the whole series of cycles and paintings.

\section{Materials and Methods}

The interest in the frescoes of Bominaco starts from some visits carried out between 2013 and 2015 together with some other more purely botanical research studies in this area.

The area of the complex is located at about $975 \mathrm{~m}$ a.s.l. and lies in the municipality of Caporciano, $30 \mathrm{~km}$ away from L'Aquila and $80 \mathrm{~km}$ from Pescara, on the Via Claudia Nova, a major Roman road axis, to which the nearby archaeological site of Peltuinum bears testimony and on which the Tratturo Magno or del Re (L'Aquila-Foggia) would also develop; inhabited settlements dating back to the period of the fortifications following the fall of the Carolingian Empire developed along this axis. Ancient pre-Roman populations of the Aterno Valley are to be attributed to the Vestini of Osco-Umbrian origin, whose relations with the Sabines of the Tiber Valley are testified by the linguistic similarities found in the paleo-Sabellian stelae of Penne S. Andrea (TE), which can be dated to the fifth century BBCE. It is important to note that these ethnic and linguistic affinities are matched by those highlighted in the figurative arts (Andaloro 1987-1989; 1990; 1991) from the Middle Ages to the Renaissance.

The climate of this area is that typical of the inland Abruzzi valleys with sharp temperature differences between summer and winter, such as in L'Aquila (continental climate, average minimum temperature of the coldest month $2.7^{\circ} \mathrm{C}$; average of the highest temperatures of the warmest month $29{ }^{\circ} \mathrm{C}$ ) and with the lowest differences as regards rainfall (in Capestrano, $500 \mathrm{~mm}$ of rain, in L'Aquila $730 \mathrm{~mm}$ ); near Capestrano, however, the presence of Mediterranean elements such as Quercus ilex, Arbutus unedo, Phillyrea latifolia and Clematis flammula is surprising, as well as olive groves that can be observed along the road from Navelli to Capestrano. The most important species characterising both the Aterno Valley and the Navelli Plain is the Goniolimon italicum, an exclusive endemic of the Abruzzi typical of cold and arid valleys, with a location near Navelli in Colle S. Eugenia. The forest vegetation (Tammaro 1998) surrounding Caporciano consists of woods with a prevalence of Quercus pubescens, as well as Acer campestre, A. monspessulanum, Fraxinus ornus, Hippocrepis emerus, and Cytisophyllum sessilifolium, in addition to Ostrya carpinifolia. The grasslands are arid, characterised by Bromus erectus or Brachypodium rupestre; in the more stony and arid areas like those above Navelli there are meadows with Stipa 
dasyvaginata subsp. apenninicola and $S$. capillata. The cultivated lands extend over the plain and feature mainly cereals with some fields specialised in the cultivation of saffron. The agricultural landscape is also characterised by the spread of almonds, with their blossoms that can be admired in the spring, but which are now almost entirely abandoned with emaciated individual specimens attacked by mistletoe (Viscum album). The spread of the almond tree in Abruzzo characterises all the anthropised and cultivated areas of the mountain zone, a sign of a landscape that is now disappearing and that still survives in some paintings, for example Cascella (1892-1989) or Cencioni (1906-1994).

In the observation of the frescoes in Bominaco, we considered whether some floral or arboreal elements depicted could have been inspired by what the authors saw directly in the area where they worked; also the research on natural landscape elements, such as fields or mountains, has also been taken into account during the visits made.

It was not possible to include photographic images of the frescoes in this work as no official request was made to the competent authority.

It is advisable however to refer to the abundant material that can be downloaded from the web at the following main links:

https://www.beniculturali.it/mibac/opencms/MiBAC/sito-MiBAC/Luogo/MibacUnif/Luoghi-della-

Cultura/visualizza_asset.html?id $=150510$ \&pagename $=57$

http://www.progettostoriadellarte.it/discovering-italia/oratorio-di-san-pellegrino-e-santa-mariaassunta-a-bominaco/

http://www.abruzzo-vivo.it/il-complesso-benedettino-di-bominaco/

http://www.spaziovidio.it/medievale/HTML/cartina/caporciano2.html

http://www.edizionizip.it/edizioni/?p=103

http://www.iluoghidelsilenzio.it/oratorio-di-san-pellegrino-caporciano-aq/

\section{The cycles of the frescoes, general overview}

The interior of the chapel consists of a single room whose walls and part of the vault are covered with frescoes with images of sacred cycles, while topmost part of the vault features a sky with floral elements and stars. The frescoes and embellishments consisting mainly of spirals with probable vine shoots and floral motifs completely cover all the spaces of the walls. Experts have identified three cycles: 1) Christ's Childhood; 2) Christ's Passion; 3) the cycle of St. Peregrine and the calendar; in addition to these cycles, there are a series of isolated figures of Saints, including St. Christopher, St. Francis, St. Onuphrius and St. Peregrine again, also depicted in the Christ Enthroned. Because of the complexity of the religious motifs, including the Last Judgment, the Oratory of San Pellegrino has been defined the "Sistine Chapel of Abruzzi".

Experts have discussed the distinction into styles of each of the cycles ascribing them to three different authors or masters, recognising a "Master of the Passion," a "Master of the Childhood," and a "Miniaturist Master," finding differences in more or less Byzantine, Gothic or Romanesque trends and thus trying to attribute each of the cycles to a different author. Comparisons with other works have been made to find historical and stylistic connections, such as with the nearby church of Santa Maria ad Cryptas in Fossa, the abbey of Sant'Angelo in Formis in Capua and with the oratory of San Silvestro ai Quattro Santi Coronati, Santa Maria in Trastevere and Santa Maria Maggiore in Rome, also considering 
the Sicilian influences with Monreale; since the dating of 1263 for the frescoes in Bominaco is certain, contaminations and influences from other more recent monuments can therefore be excluded, while it is certain that the extension of the monastic orders up to the more isolated rural locations facilitated the spreading of similar themes. Apart from these issues, our analysis allowed us to identify the floral and naturalistic elements in the representations, whose comparison perhaps makes it possible to also find differences in the stylistic sensitivity of the different painters.

\section{Botanical iconography and interpretation}

\section{The cycle of Christ's Childhood}

a) The Nativity. In the box we can see a composition and a movement of lines (the cave, the position of the Infant in swaddling clothes and of Saint Joseph, etc.) that follow those that can be observed in the Palatine Chapel of Palermo, where the coloring tends though towards an intense green, while in the fresco in Bominaco the shade tends more to reddish, which unsurprisingly stands out in all the paintings (this "warm" shade intensifies the participation of the faithful). The only relevant floral elements are the stylised three-pointed lily motif adorning with a line the perimeter of the table-manger (or canvas stretched over it) on which the Child rests and a naturally shaped lily adorning a circular base of a tub for bathing.

b) The annunciation to the shepherds. The box referring to the Gospel of Luke is located to the right of the previous one and shows an Angel holding a cartouche with the word "Gloria" (Glory). His gaze is turned to the faithful, as he flies over the scene where the shepherds are surprised with their sheep; a fourth shepherd on the left seems to enter the scene at that very moment under a tree like a pilgrim with a stick and a saddlebag on his shoulder.

1) The mountains. This is the most naturalistic scene of all the cycles because the panorama opens wide on the grazed meadows towards the background where several tall mountains rise, at least seven of which can be clearly distinguished (a reference to the three messianic mountains?). The mountains have a conical shape, they seem almost volcanoes, and show a clear separation between a lower and an upper part; the first is crossed by long slopes, the second is covered by simplified rocks with curved lines (there are different types represented in other Byzantine examples and in Giotto where the mountains are seen as smooth and angular rocks). An identical shape of a mountain divided into two parts, high and low, indicated in the literature as a "pine cone head", is found in the oratory of San Silvestro ai Quattro Santi Coronati in Rome in the depiction of the discovery of the true Cross in Jerusalem by St- Helena, Constantine's mother; there we also observe the scene of Constantine's envoys ascending Mount Soratte to find St. Silvester and the mountain is painted in the same way (in this case we do not want to emphasise the altitude, but rather the remoteness of the place). The detail of the furrowed slopes refers to what was observed personally in the neighboring areas (Fig. 1), where the slopes of some mountains between Navelli and Ocre showed evident ploughed furrows; briefly, the distinction between a high 
and a low part establishes the almost net transition between the cultivated "civil" area and the "wild" one where rocks and snow seem to keep humanity at a distance. Only three of the seven mountains have this aspect, while the other four are clearly less elevated. It is quite evident that the painters were impressed by the majesty of the high peaks around the Gran Sasso and depicted them as rocky and inaccessible peaks. While for Bominaco we have a precise dating - 1263 - the frescoes of San Silvestro in Rome are believed to date from the second half of the thirteenth century, therefore more or less in the period of time. It is possible that the artists of Bominaco and Rome knew each other, but it is also probable that the painters of that time used sketches which through communications between the different monasteries areas could be an easy tool for disseminating works.

2) Trees. The two trees to the left of the box have a strange twisted shape with bare branches that end only towards the tip with a stylized conical crown where the leaves emerge clearly; this shape is typical of other figures at Byzantine sites also distant from each other, while to see a tree in a more natural form with distinct individual leaves we need to return to the Gothic Hall of the Quattro Santi Coronati; in the Calendar for the month of May we observe a man on a tree picking fruit; the tree is clearly a cherry tree due to the shape of its leaves and fruits (in this case the inspiration of the style is no longer Byzantine but northern Gothic). The stylised Byzantine forms of the tree crowns are a constant motif in Byzantine painting, where the main focus is the overall perceived vision in its stylized form rather than the details.

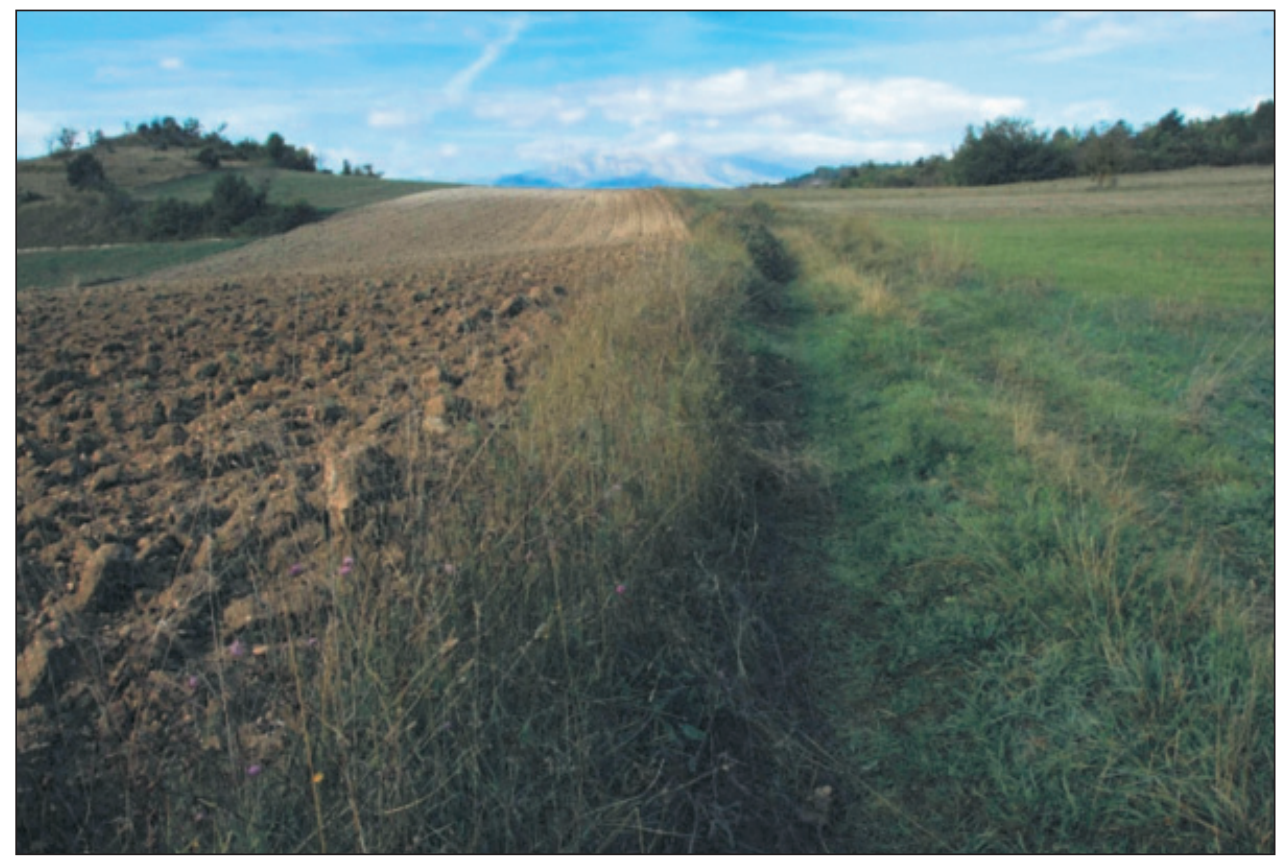

Fig. 1. Landscape of ploughed fields in the Navelli plain with the background of the Gran Sasso. 


\section{The cycle of Christ's Passion}

a) The Deposition in the Sepulchre. The box shows the deposition of the dead Christ, a theme, as Della Valle (oc) says, is present extensively in the Byzantine tradition, although in this case the Byzantine influence is less felt throughout the cycle, as ancillary characters such as the angels disappear, while Mary Magdalene is present, holding a hand of Christ.

1) The sarcophagus. An interesting aspect is the sarcophagus in which Christ is deposed because it does not seem to be a real sarcophagus but a bed instead. From a botanical point of view, it is interesting to note the depiction of Christ placed on a cloth, almost a carpet, the weft of which is visible; on the front side a white cloth descends, where ten similar plants are painted aligned with large oval acuminate leaves. It is not possible to assign the plants to a particular species, but it seems that the flowers represent the recurrent symbology of the lily. The shape of the leaves is oval, almost heart-shaped (a detail that also recalls violets, but which we have not observed other times, since the herbs are almost always painted as linear, except for some cases, such as the acanthus), establishing a connection with Christ's heart, whose devotion began in the Germanic world in more or less the same period as that of the frescoes. The choice of a violet could be related to the liturgical colour for mourning and the Passion. Careful observation revealed to us us that, from left to right, of the ten plants six are in the vegetative state of only leaves, three are with flowers, and the last one on the right has flowers and fruits; it is also evident that the last four plants on the right have fewer leaves than those on the left, as happens in real life when a plant reaches maturity. It seems almost obvious that this detail, missed so far as in the texts, conveys an important meaning in relation to the cycle of life, from birth to death. As the flower dies, the fruit is born and from it the seeds propagate new life, as the Evangelists wrote: "it is from death that life is born" (Matthew 10:39; John 12:24) and so Tertullian repeated: "the blood of martyrs is the seed of new Christians." This particular plant also denotes the spiritual sensitivity of the painter who does not limit himself to copying what was already visible in other works, also nearby, such as in San Pietro in Vineis in Anagni (bare marble sarcophagus, unique and cold expression of death) or in other more cheerful representations of flowering lilies arranged in a row in the San Silvestro cycle in Rome.

2) Columns with capitals. Another plant motif in this box can be found in two columns placed set against the background of a blue sky and between which a candelabrum hangs from above. The columns are not smooth but seem to have a tortuous line that could recall the paschal candle of the nearby church of Santa Maria Assunta which may have inspired the painters; the colours too reveal a redder column on the left and a whiter one on the right, as can be seen also in the panel of the Annunciation, in which the two columns are very similar. What is most striking are the three leaves (or a single large leaf divided into three lobes) that act as capitals. These too are similar to those in the panel of the Annunciation; it seems obvious that we are dealing with acanthus according to a Graeco-Roman tradition in use for centuries, but the form can lead to identifying another aspect. In the Benedictine context, in fact, the cultivation of the fields and the construction of vegetable gardens annexed to the monasteries developed. The Benedictines cultivated medicinal herbs and food, activities that were already important in the field of Byzantine monasteries (see Littlewood \& al. 1996). It does not therefore seem completely unlikely that the painter could have used cabbage leaves as a model and that therefore the capitals of some columns of the Bominaco frescoes are more likely to be cabbage leaves (Brassica oleracea L.) In its varieties of black 
cabbage or curly kale, a very important winter vegetable in the medieval diet for both humans and animals. Even today, the cabbage in all its varieties, including the coloured ones, is used as an ornamental plant for the beauty and elegance of the leaves, so it is not surprising that in a strict context such as a monastery cabbage was taken as a vegetable model to replace the acanthus. In other ornamental motifs in the frescoes of Bominaco a large cabbage leaf shape with a pinecone-shaped element at the centre could be a cauliflower rather than an acanthus or lotus fruit or a pinecone proper. However, this interpretation has not been confirmed yet since the cauliflower was not known in medieval Europe and seems to have been introduced from the East (perhaps originating on the island of Cyprus) around the fifteenth century (Smith 1995). An attribution of cauliflower in this case would be justified by the fact that the painter might have thought of references to eastern Byzantine motifs, where this vegetable was already known.

\section{Conclusions}

The building of the Oratory of San Pellegrino has very small dimensions $(18.70 \times 5.60$ $\mathrm{m})$, but the unique shape of the vault enhances the space thanks to an incredible amount of floral decorations (spirals and festoons with lilies) to which eight-pointed Byzantine stars are added; this exaltation of a space, in which the effect of "horror vacui" is achieved with the explosion of flowers and images, creates an immediate feeling of wonder in visitors and a moment of spiritual ecstasy towards the divine among the faithful. The name of "Sistine Chapel of the Abruzzi" does not therefore seem inappropriate and if in the Vatican the idea is to exalt divine power, the small Oratory wants to offer a moment of peace and contemplation, as a pilgrim seeks along his path that is not only physical, but also the inner one of mind and soul while walking. This space can therefore be seen as a "shelter" from the external sensitive world in an internal supra-sensitive sphere.

As for the naturalistic figures, from the landscape of the mountains to the shape of the trees and the stylised flowers, in addition to the repeated Byzantine canons, we can see an approach rooted in reality both in the series of plants seen in their life cycle of flowering and in the probable figures of cabbage and cauliflower, both in an effort to represent the shapes of trees with twisted branches and with the crowns that are not only flat but take on a vibrant movement. This same effect is obtained in the paintings of the great expressionist painters, such as in Van Gogh where the trees, cypresses or olive trees, are outlined by dense foliage with strong sinuous lines. An expressionistic approach to the Byzantine style is mentioned by several authors and in particular by Gatto (2016-2017), finding Byzantine motifs in the art of El Greco, Matisse, Cezanne, Kandiskij, and Klimt; in Roualt's works, the spiritualism that imbues every original Byzantine work reappears. In Sironi, in the Sapienza cycle in Rome and in the Palazzo di Giustizia in Milan, every three-dimensional form disappears and everything becomes two-dimensional, returning to forms of mosaicism (Gatto 2016-2017).

\section{References}

Andaloro, M. 1987-1988, 1988-1989: Studi sull'arte medievale in Abruzzo. - Chieti. 
- 1990: Connessioni artistiche fra Umbria meridionale e Abruzzo nel Trecento, in Dall'Albornoz all'età dei Borgia: questioni di cultura figurativa nell'Umbria meridionale. - Pp. 305-346 in: Atti del Convegno di Studi (Amelia, 1987). - Todi.

- 1991. Abruzzo. - Pp. 60-73 in: Enciclopedia dell'Arte Medievale, 1. - Roma.

Arbace, L. (ed.) 2012: Bominaco. L'oratorio affrescato e la scarsella di San Pellegrino. - Pescara.

Baschet, J. 1991: Lieu sacré, lieu d'images. Les fresques de Bominaco (Abruzzes, 1263), thémes, parcours, fonctiones. - Paris.

Dander, M. 1979: I tesori di Bominaco. - L'Aquila.

De Dominicis, A. 1970: Bominaco e la sua abbazia. Guida storico-artistica. - L'Aquila.

Della Valle, M. 2006: Osservazioni sui cicli pittorici di San Pellegrino a Bominaco e di Santa Maria ad Cryptas di Fossa in Abruzzo. - Viterbo.

Gatto, G. 2016-2017: Estasi dell'oro e il profumo della decadenza. La riscoperta dello splendore bizantino fra estetica, letteratura e arte. - Dissertation, supervisor G. Trovabene, Univ. Cà Foscari di Venezia, Dip. Filosofia e Beni Culturali.

Lo Jacono, S. 1995: Bominaco. Spiritualità, Cultura, Fierezza di un'Abbazia Benedettina. - Pescara.

Smith, D. R. 1995: Flower development: origin of the cauliflower. - Curr. Biol. 5(4): 361-363. https://doi.org/10.1016/S0960-9822(95)00072-8

Tammaro, F. 1998: Il paesaggio vegetale dell'Abruzzo. - Penne.

Address of the author:

Fernando Lucchese,

Dipartimento di Scienze, Univ. Roma Tre, viale G. Marconi 446, 00146 Rome.

E-mail: fernando.lucchese@uniroma3.it 